\title{
Montessori, Waldorf, and Reggio Emilia: A Comparative Analysis of Alternative Models of Early Childhood Education
}

\author{
Haifa Aljabreen ${ }^{1}$
}

Accepted: 25 November 2020 / Published online: 12 December 2020

(C) The Author(s) 2020

\begin{abstract}
Montessori, Waldorf, and Reggio Emilia education remain three of the most popular models for alternative early childhood education. Each of these approaches has developed globally, with a rich history of supporting children's educational freedom. This narrative analysis provides a means for early childhood educators and scholars to understand the aims, philosophical and theoretical frameworks, historical development, benefits, and challenges in these models and their methods of practice. As early childhood education evolves with technology and as re-conceptualizations about early education occur, an understanding of these alternatives to traditional education models is important. While adaptive options of these models may emerge in education systems across national contexts, this review allows educators to consider their applications and cultural appropriateness in specific local and community contexts.
\end{abstract}

Keywords Early childhood education · Pedagogy · Curriculum models · Montessori · Reggio emilia $\cdot$ Waldorf education

\section{Résumé}

Montessori, Waldorf, et Reggio Emilia restent trois des modèles les plus populaires d'éducation préscolaire. Chacune de ces approches s'est développée à l'échelle mondiale, avec une riche histoire de soutien à la liberté d'éducation des enfants. Cette analyse qualitative permet aux éducateurs de la petite enfance et aux chercheurs de comprendre les objectifs, les cadres philosophiques et théoriques, l'évolution historique, les avantages et les défis de ces modèles et leurs méthodes de pratique. Comme l'éducation de la petite enfance évolue avec la technologie et des reconceptualisations de l'éducation des jeunes enfants existent, il est important de comprendre ces alternatives aux modèles traditionnels d'éducation. Dans la mesure où des options

Haifa Aljabreen

hjabreen@moe.edu.sa

1 Early Childhood General Administration, Ministry of Education in Saudi Arabia, Riyadh, Saudi Arabia 
adaptatives de ces modèles pourraient émerger dans les systèmes éducatifs de divers contextes nationaux, cette analyse peut permettre aux éducateurs d'examiner leurs applications et leur adéquation culturelle dans des contextes locaux et communautaires spécifiques.

\section{Resumen}

La educación Montessori, Waldorf, y Regio Emilia siguen siendo los modelos de educación preescolar alternativa más populares. Cada uno de estos métodos ha sido desarrollado en todo el mundo, con una rica historia de apoyo a la libertad educativa de los niños y niñas. Este análisis cualitativo brinda un medio para que los educadores e investigadores de preescolar comprendan los objetivos, marcos filosóficos y teóricos, desarrollo histórico, beneficios y retos de estos modelos y sus métodos prácticos. En la medida en que la educación preescolar evoluciona con ayuda de la tecnología y ocurren nuevas conceptualizaciones sobre la educación preescolar, es importante comprender estas alternativas a los modelos de educación tradicional. En la medida en que adaptaciones de estos modelos surjan en los sistemas educativos en todos los contextos nacionales, este análisis puede permitirles a los educadores considerar sus aplicaciones y validez cultural en contextos locales y comunitarios específicos.

\section{Introduction}

Understanding and awareness of alternative models for delivery of early childhood education programs is a starting point to advance early childhood learning and opportunity. This overview presents the unique aspects of three alternative curricula-Montessori, Reggio Emilia, and Waldorf education-including comparisons between these models and consideration of their suitability for wider implementation internationally. Many preschool communities, particularly systems outside the United States, lack understanding of other educational models and could benefit from other cultures' use of options at the early childhood level (Hyun 2006; Rogoff 2003; Phillips and Schweisfurth 2008). This narrative review of Montessori, Waldorf education, and Reggio Emilia is an attempt to strengthen the larger field of international early childhood education.

The education models discussed already have international applications. For example, Montessori education has been international almost since its beginning, and because of its international focus historically, it is considered easily adaptable to other cultural contexts (Edwards 2002). The importance of the child in determining directions for his/her own learning is a theoretical basis for all three approaches. The curriculum for each model emphasizes the role of natural materials and settings, holistic child development, and peaceful conflict resolution. "All three approaches represent an explicit idealism and turn away from violence, toward peace and reconstruction,... built on coherent visions of how to improve human society by helping children realize their full potential as intelligent, creative, whole persons" (Edwards 2002, p. 3). 
Integration of alternative educational approaches in any culture will bring both benefits and challenges for children, parents, and teachers. Educators have to consider whether the American or European ideas of Reggio Emilia, Montessori, or Waldorf education would present feasible changes in thinking, traditional cultural habits, or attitudes can apply in non-Western nations. If the differences are significant enough, adaptation of an educational approach may be nearly impossible (Firlik 1996). One guiding statement in this area comes from Saudi researcher Al-Mogbel (2014): "The adoption of the concepts of quality education can only be achieved through informed interactions about educational experiences in other states and communities" (p. 2074). Learning from other nations' experience is valuable as countries explore new options.

\section{Montessori}

The Montessori educational model was designed in the early 1900s in Rome, Italy, by a physician, Maria Montessori (Edwards 2003). "After innovating a methodology for working with children with disabilities, she started her Casa dei Bambini (Children's House) in 1907 for children aged 4-7 in a housing project in the poor slums of Rome" (Edwards 2003, p. 35). The Montessori educational approach became extremely popular in Italy and for a short time in the United States; then its popularity shifted to Europe and India. "Her ideas apparently turned out to be too radical for the educational mainstream" (Crain 2011, p. 72) until they were revived in the United States in the 1950s by educational pioneer Nancy Rambusch. One of the core ideas behind this system is that children guide the learning process at their own pace. Nancy Rambusch (2010) clarified the original Montessori vision: "Dr. Montessori's educational aims were two-fold: to help the child develop and to help him adapt himself to the physical conditions of his environment and to the social requirements dictated by the customs of the group in which he lives" (p. 39).

Montessori's own theories regarding child development are quite distinct and historically strong and are often cited as a framework to inform other educational theories. Similar to Dewey's constructivist theory, the Montessori model features a developing child, specifically one who is involved in constructing his own learning experience (Rathunde 2001), with a teacher who is creating a supportive child-centered environment (Mooney 2013). As a constructivist, Montessori's belief in developmental periods shares aspects of Piaget's theory regarding a child's spontaneous interest in learning; the significant difference between the two is in the exact periods or stages designated (Edwards 2003; Crain 2011). The Montessori model reflects, as well, the psychology of Abraham Maslow on the importance of meeting the developmental needs of the whole child through experience in natural learning surroundings (Weinberg 2011).

\section{Aims}

The aims in the Montessori model place an emphasis on whole child-development, as well as learning support by the teacher who is a guide for the child's learning. 
Maria Montessori believed in whole-child development and that learning involves growth of both mind and heart through the classroom experience (Edwards 2002, 2003). Weinberg (2011) explains this goal according to the philosophy of the founder: Montessori (1967) stated that "education must not be understood in the sense of teaching, but of assisting the psychological development of the child" (p. 28). This support of not only the rational part of the child, but also his spiritual side, is a distinctive aim of Montessori education: "Every element of Montessori methodology is designed for the care of the soul" (Weinberg 2011, p. 16), including concepts of "calmness, clarity, courage, compassion, wonder, joy, creativity, connection, and playfulness" (Smith 2013, p. 47).

Montessori believed in the value of the individual child and his/her development based on interests, pacing, and skills (Deluca and Hughes 2014; Lillard 1997). Though her philosophy addressed the full years of child development through high school (Crain 2011), she believed in particular that the early child stage is vital on its own, not just as preparation for later stages (Montessori 1967). This stage of early childhood, Montessori believed, is the time of the child's most "sensitive periods" for growth, when "the child is especially eager and able to master certain tasks" (Crain 2011, p. 73). Educators in this system aim to "recognize the dignity of children and appreciate the developmental importance of their spontaneous activity in an extended childhood" (Rathunde 2001, p. 20).

To support the Montessori view of the complete development of the individual child, according to his/her personal interests, the Montessori teacher works as a guide (Cossetino 2009). "The Montessori teacher plays the role of unobtrusive director in the classroom as children individually or in small groups engage in self-directed activity" (Edwards 2003, p. 37). Edwards (2002) describes this beautiful balance of Montessori teacher-guide and child-directed interest: "During the early childhood years, the teacher brings the young child into close contact with reality through sensory investigation and practical activity and then relies on the child's unfolding inner program of curiosities and sensitivities to ensure that the child will learn what he or she needs" (pp. 7-8). The teacher's management of the environment and learning process are all constructed to support the child's interests.

Based on a relationship of trust, the Montessori teacher supports children's relational development with each other also, helping students to develop increasing selfdiscipline and self-control, and only stepping in to help when necessary in a student disagreement (Edwards 2003). The Montessori teacher does not allow any disorderly or mean behavior and deals with problems in a way that teaches the child what is allowed and how to correct the problematic behavior (Lillard 1997). Edwards (2002) frames this relational purpose of Montessori education in this way: "The teacher's goal is to help and encourage the children, allowing them to develop confidence and inner discipline so that there is less and less need to intervene as the child develops" (pp. 7-8). She recognizes the importance of good peer relationships and strong peer culture (Lash 2008), where the teacher gives the children room to enjoy good friendships. Teachers in the Montessori approach are carefully prepared for this role as guide. The required training is intense and specific, focused on "mastering the technique" (Cossetino 2009, p. 524). 
Practical measures to prepare the teachers include training in exact procedures of instruction or activity within the classroom. The teacher must learn a great number of particular terms, scripted steps and explanations of materials, and "mastery of a large and complex technical repertoire, which is directed toward the moral and spiritual goal of fulfilling human potential" (Cossetino 2009, p. 526). Teachers are presented with almost exact scripts for instructing children in the use of materials. These demonstration methods are precisely taught according to Montessori's belief that careful, repeated teaching by a supportive, observant guide will provide stability for a capable, developing child (Cossetino 2009).

\section{Curriculum}

The early childhood curriculum for the Montessori school is largely based on presentation of specific materials. "Children pursue individualized study using a large array of didactic materials" (Cossetino 2009, p. 525) that feature hands-on usefulness, movement, and color. The materials teach through activity, developing skills of math, color, size, reading, and writing.

\section{Focused on Child Interests}

Of key importance in the curriculum is that the student is learning what interests him/her. Children, Montessori believed, enjoy long work periods (Lillard 1997). As Montessori (1967) explained, "the teacher must believe that this child before her will reveal his true nature when he finds a piece of work that attracts him" (p. 276). Within the morning period of guided curriculum use, the dominant process is for each child to choose activities for himself/herself, progressing as far as he/she is interested. "The individualization results in some young children mastering reading and writing before age 6 following Montessori 'writing to read' methods" (Edwards 2002, p. 6).

\section{Guided Use of Materials}

The role of the instructor in this curriculum is to function as a guide for students capable of self-regulation. Working often in teacher teams (Edwards 2002), these teacher-guides are responsible for careful demonstration of materials before students are ever using them by themselves. The early childhood Montessori educators present the next object "at the point when an individual or small group indicates readiness to advance in the sequence of self-correcting materials, in the areas of practical life, sensorial, mathematics, language, science and geography, and art and music" (Humphryes 1998). Since the child is considered able and strong, and the materials are self-correcting, the curriculum develops, in large part, according to children's interests in and skill in using these materials. 


\section{Assessment of Learning}

The core of assessing each student's unique capabilities and skills within this model is based on non-traditional teacher presence (Deluca and Hughes 2014), teacher observation, and individual student work portfolio development, including educator interpretations of the child's work (Edwards 2003; Deluca and Hughes 2014). Montessori does not use traditional paper or test assessment methods; teachers instead are listening to student responses as they develop physical and mental skill in using the materials (Deluca and Hughes 2014).

\section{Waldorf Education}

Waldorf education was founded in 1919 by a philosopher named Rudolf Steiner (1861-1925) in Stuttgart, Germany. Workers in the German Waldorf-Astoria Cigarette Factory in Stuttgart coordinated with Steiner to create a school for their children (Nordlund 2013). The Free Waldorf School was based on the belief that humans will develop naturally if given the opportunity to explore their natural surroundings. Easton (1997) explains that Steiner's motivations in creating this model focused on issues related to technology's dehumanizing effect on the culture: Steiner's "purpose was to create a new impulse in education that would enable children from diverse backgrounds to develop the capacities necessary to cope with the demands and challenges of a post-industrial world" (p. 88). The school opened as a comprehensive educational system-preschool through high school (Damovska 2005; Edwards 2002). The key characteristic of this model was its blended focus on the science of humanity and the spiritual nature of children-combined in Steiner's concept of "anthroposophy" (Edwards 2002). Originally most popular in Western Europe only (Damovska 2005), this method provides today's youngest learners with opportunity to develop their full human potential "in a world that is becoming increasingly mechanized" (Easton 1997, p. 88).

\section{Aims}

Waldorf education places the focus on a child's freedom and holistic child development. There is also a role for the teachers as a guide for the child and as an artistic director.

The strongest characterization of the child within Waldorf education is the picture of a free, developing human (Damovska 2005). The development of this personal freedom to its greatest potential is the goal of the Waldorf educational system. "The object of Rudolf Steiner education is to aid children so that as men and women they may bring their powers, their own innate and sacred human qualities, to greater fulfillment. It is an education which serves the freedom of the human spirit' (Edmunds and Barton 2004, p. 9).

Waldorf works to develop the whole child (Deluca and Hughes 2014; Barnes and Lyons 2003; Nordlund 2013; Damovska 2005), particularly in the area of artistic 
appreciation and love for the value of beauty (Edmunds and Barton 2004; Easton 1997). One of the phrases that researchers regularly use to picture this ideal of whole-child education is "head-heart-hand" (Easton 1997; Damovska 2005; Chauncey 2006). Others, following Steiner directly, use the terms "willing, feeling, thinking" (Barnes and Lyons 2003; Nordlund 2013; Edwards 2002). Similarly, to other alternative educational designs, the Waldorf approach is focused on the unique needs of each child. Waldorf education pictures child development in seven-year stages (Easton 1997). During all of these time periods, the child is still the same free, developing, teachable human being. "The little child longs to enjoy spontaneous freedom-but within the clearly defined security of order and form" (Barnes and Lyons 2003).

Teachers in the Waldorf systems provide guidance for these developing children, always supporting their interests and learning in the areas of the arts: goodness, beauty, and truth (Edwards 2002). Dealing with the child behavior issues in the Waldorf classroom is often approached by a change of activity, introducing a new story or providing the child with an art project (Edmunds and Barton 2004). The activity of storytelling is a crucial part of Waldorf education, led by the educators themselves. "Waldorf class educators are artists and performers; they are trained in visual and performing arts and called to think innovatively about lessons" (Nordlund 2013, p. 18).

According to Deluca and Hughes (2014), typical Waldorf classrooms include two teachers who are learning from the children and from colleagues (Clouder and Rawson 1998). Teachers in a Waldorf school meet together regularly for collaboration (a group referred to as the Community of Teachers or College of Teachers), working to support each other and determine administratively the plans for the school's progress (Nordlund 2013). Each educator is trained with a combination of both traditional teacher education and direct Waldorf college certification (Nordlund 2013; Pope-Edwards 2002).

\section{Curriculum}

The foundation for Waldorf curriculum is the Waldorf approach in understanding the development of the child. Generally, the child is featured in the curriculum as a developing individual, growing in his/her understanding of beauty. Every learning stage is committed to featuring "learning activities that are comprehensive of multiple intelligences and interdisciplinary in nature" (Nordlund 2013, p. 14).

\section{Early Childhood and Imitation}

The progression of development begins with the youngest children learning to imitate the teacher (Nordlund 2013). For nursery or preschool or kindergarten, the goal is "learning through doing" (Edmunds and Barton 2004, p. 18). At these youngest ages, Waldorf education practices the philosophy that "stories, songs, quality materials, and behavior worthy of imitation stimulate physical growth, language development, and curiosity, thus laying a sound foundation for the later development of 
imagination and thinking" (Easton 1997, p. 88). Waldorf chooses to wait for the introduction of some of the early curriculum content areas until later in the child's development. "No kind of formal schooling begins, no reading, writing, arithmetic or regimentation of any kind" (Edmunds and Barton 2004, p. 17) so that children do not "grow up" too early or lose their energy for later learning or their enjoyment of playing.

\section{Open Approach to Curriculum Content}

The Waldorf program has been described as an open curriculum. The learning and educational methods and contents are adapted depending on the age of the child as well as their physical and spiritual needs and capacities" (Damovska 2005, p. 38). Content, for the Waldorf educator, is experience-focused, "not constructed to acquaint children with particular factual material or critical thought processes. Rather, all subjects provide an occasion for imaginative perception and conception" (Kane 2011, p. 125). The general learning process is sequential: "First, in the Rudolf Steiner or Waldorf method, comes the encounter; then encounter becomes experience; and out of experience the concept crystallizes.... These are the three steps in every genuine learning process" (Barnes and Lyons 2003, p. 17). Games are included in curriculum as opportunities for fun and physical activity (Edmunds and Barton 2004). Teachers' stories and the children's journals supply many of the learning opportunities. The main emphasis is on creativity, singing, reading, and acting. There are no electronic media in the classroom based on a belief that technology will harm children's developmental capabilities and creative nature.

\section{Arts-Focused}

One of the primary methods used to communicate the Waldorf curriculum is natural art activities, developing the child's spiritual sensitivity and awareness of the world around him/her (Dancy 1989; Easton 1997; Lim 2004; Walsh and Petty 2007). The "Waldorf method advocates teaching as an art by creating an aesthetic environment, and presenting subject matter in an artistic way" (Easton 1997, p. 90). This fundamental element of the curriculum is based on the theory that "education is an art" (Barnes and Lyons 2003, p. 17). With the "hands-on, arts- and outdoors-based integrated curriculum" (Deluca and Hughes 2014, p. 443), children can experience significant imaginative development.

\section{Storytelling}

Traditional storytelling exists as another primary method for teaching language and history in the Waldorf approach (Easton 1997). In the dramatic communication of stories for the Waldorf student, "teachers tell, rather than read, stories in an expressive voice, modeling a quality the class is expected to imitate in group recitations" (Easton 1997, p. 90). After a teacher presents a concept through story or dramatic telling, children are often given the opportunity to respond in artistic expression (Edwards 2002, p. 5) or enjoy imaginative play. 


\section{Assessment}

Curriculum assessment occurs non-traditionally through observation (Deluca and Hughes 2014). The Waldorf teachers take a holistic approach to curriculum assessment - the whole student is closely observed individually: "A child-study is when the entire faculty observes one child, in all aspects of schooling, for 2 weeks... Then, the faculty meets to share their observations of the child with the aim of formulating a 'helping question,' asked from the child's perspective" (Deluca and Hughes 2014, p. 453). This concept of embodied assessment is "not paper-based but rather was physical, oral, and play-based" (Deluca and Hughes 2014, p. 455). The Waldorf approach believes that "by focusing on the child--valuing and being present to children-primary teachers are able to individualize their assessment and instruction for learning" (Deluca and Hughes 2014, p. 452).

\section{Reggio Emilia}

Reggio Emilia was founded by the visionary Loris Malaguzzi (1920-1994) to provide provisions for children of the city of Reggio Emilia, Italy, after World War II (Wien 2008). Italian families had experienced the horrors of war with oppressive education and very limited opportunities for development. This program offered hope and freedom for children who were growing up in a world recovering from Fascism. The Reggio Emilia program began with teachers and families working together to create schools within the Italian public education system for the very youngest children. The parent cooperative movement (New 2000) developed into a municipal organization with leading ideas for child development that have spread across the globe.

Rinaldi (2006) underlines the role that spatial environments play in Reggio Emilia schools. The concept of physical space is explored as a language, as a primary aspect of thought development, envisioned as a third teacher (Wien 2008) that establishes a context through which the curiosity and creativity of children are listened to and accepted, "a classroom atmosphere of playfulness and joy" (Edwards 2003, p. 37).

The founder, Loris Malaguzzi, identified multiple theories as contributing to his ideas as an educator, primarily the social constructivism of Vygotsky, Piaget, and Montessori (Lim 2004; Dodd-Nufrio 2011; Firlik 1996; Edwards 2003), as well as the progressivism of Dewey (Edwards 2003), and the human psychology of Bronfenbrenner, Bruner, and Gardner (multiple intelligences) (Hall et al. 2014). Based on the image of the child as a competent constructor, "Reggio Emilia educators believe that the school is not a place of transmission of knowledge. Rather it is an environment that allows the child to be a producer of culture and knowledge-the child is a knowledge maker" (Dodd-Nufrio 2011, p. 236). Today, "Reggio Emilian preschool is best described as that of a constructivist learning theory. Constructivists state that children construct their knowledge and values from interactions with, and actions on, the physical and social world" (Firlik 1996, p. 217). 


\section{Aims}

Three aims of the Reggio Emilia school of thought have been identified: the rights of the child, the importance of the role of the teacher as a professional researcher, and community partnerships in the education of the child.

One of the primary goals in the Reggio Emilia school is to conduct learning experiences with an emphasis on the rights and value of the child in the education process. "The keystone in the Reggio philosophy...is the image of children and teachers as capable, resourceful, powerful protagonists of their own experience" (Wien 2008, p. 6). The audience of the program has always been infants, toddlers, and preschool- or kindergarten-aged children (Edwards 2002). These children must be allowed to touch, move, listen, see, taste, discover, and explore the world around them in an enriching and supportive environment. The child is rich, competent, and naturally creative (Olsson 2009), an individual that has rights to creativity (Rinaldi 2006). Children are supported in their ability to express in any of a hundred different languages the ideas that they are processing (Edwards et al. 2012; Vakil et al. 2003). The child is given every opportunity to use "words, movement, drawing, painting, building, sculpture, shadow play, collage, dramatic play, music" to share the thoughts of his heart and mind (Edwards 2002, p. 6). At the center of Reggio Emilia pedagogy is the vision of a competent, critical, and active child.

A second aim of Reggio Emilia education concerns an image of teachers who are knowledgeable, professional researchers (Olsson 2009), actively interweaving theory and practice-learning, doing, and reflecting. In contrast to top-down curriculum traditions which rely on outside educational researchers, Reggio Emilia teachers are acknowledged as sources of research and consider research as their permanent attitude and a technique for their work. Their role includes a variety of activities_-recording, dialogue, discussion (Edwards 2003), listening (Olsson 2009), relationship-building, and scaffolding the child's learning by seeking to understand him/her. "The Reggio teacher plays a role of artful balancing between engagement and attention" (Edwards 2012). But in the end, the goal is learning, studying the child thoroughly, gathering every bit of info possible about the development of that particular individual (Hertzog 2002).

A third aim of Reggio Emilia is its focus on partnerships in education. "There is a cooperative spirit that galvanizes the expectations of all those who hold a vested interest in the work of the school.... The relationships that are sustained between home and school" are strong and documented (Vakil et al. 2003, p. 189). The structure makes teachers, children, and parents equal participants in the academic or learning programs. In Reggio Emilia schools "parents and other community members are involved in school decision-making processes through their participation in school-based parent-teacher boards, as well as on community-wide committees that report to the town council" (Firlik 1996, p. 217). The Reggio Emilia institution is a collaborative cultural space where the public can participate in the functional, methodological, and organizational aspects of the learning system (Edwards 2003).

Supported by the partnership with other educators, parents, and members of the community, teachers work to observe, listen, reflect and learn about the children in their care (Olsson 2009). One of the elements that makes this extensive 
research-learning possible for the teachers is the longer-term relationship they have with the same students: teacher and children commonly stay together for three years (Edwards 2003). The "Reggio Experience" (Edwards 2003) is led by a pedagogista (specialist, coordinator) (Edwards 2003). The teachers often work in pairs (Rinaldi 2006) planning each week (Firlik 1996), designing their support of each child's development, organizing rich environments for educational, problem-solving opportunities (Rinaldi 2006), and documenting learning in each context (Hertzog 2001). Additional art leaders, called atelioristas, are specially trained in the visual arts to encourage expression through media and symbols.

\section{Curriculum}

According to Rinaldi (2006), the terms "curriculum planning," "curriculum," and "professional development" are inappropriate to convey the sophisticated, complex nature of the Reggio Emilia approach and process. The Reggio model instead presents the word progettazione as the "technique of thinking, a way of establishing relations, as well as bringing in the aspect of chance or rather the space of other people" (Rinaldi 2006, p. 133). Since Reggio Emilia underlines the principles of community, responsibility, and respect, emphasizing the use of the child's interests as the basis for learning rather than the knowledge of the teacher (Rinaldi 2006), it is crucial that methods and content be self-guided, customized, and flexible. The negotiated, emergent curriculum is "not tied to schedule, not in a huge rush to accomplish specific lessons each day, very flexible periods of work and play and engagement or breaks" (Hertzog 2001). Because the teacher and students are not operating a tight program of events, in-depth learning is much more possible than in traditional classrooms (Firlik 1996).

\section{The "Project" Method}

If there is a defined, identifiable core component of the Reggio Emilia curriculum, it is the concept of the in-depth project. "Long-term, open-ended projects are important vehicles for collaborative work" (Edwards 2003, p. 35). The curriculum is recognized for its presentation of "the arts in a beautiful, healthy, and love-filled setting, and especially for its use of projects focusing on children's expressive capabilities manifested in a variety of ways" (Lim 2004, p. 114). Hertzog (2001) describes the large art room present in each Reggio school, as well as a small artistic center in each classroom (atelier) — full of colors and materials, many from nature. "Teachers at Reggio Schools suggest using 'abundant materials' for painting: tempera and watercolor paint in many shades and tints in clear glass jars, many brushes in different sizes, papers of all colors, sizes, and qualities" (Lim 2004, p. 115). Teachers and students work and make decisions together about what to add or change, discussing content, opinions, and emotions connected to the art.

The method of using Reggio projects has a definite purpose for both children and teachers: "to make the learning experience "visible"" (Hertzog 2001, p. 4). The child's art shows what he/she is thinking; and the educator's documentation portrays 
what the teacher is hearing from the child, demonstrating in a daily journal for parents what is going on each day (Hertzog 2001).

\section{Assessment}

As the term project defines the student curriculum, the term documentation best identifies the teacher activity of describing the learning taking place in this "curriculum." Teachers observe, record, and then read and interpret observations of the children's project work. The valuable resulting portfolio of information created by the child with his/her teachers is passed on through the school system as a helpful, useful record of learning. This documentation would be considered the primary mode of assessing Reggio students' work (Vakil et al. 2003), taking many forms: "Journals, daily reflections, and panels of children's work displayed in various media invite a shared discourse that is honest, explicit, and synergistic" (Vakil et al. 2003, p. 189); “displays of photographs and examples of children's work as well as teachers' recordings and note taking of conversations, provide records of children's development" (New 1992, as cited in Walsh and Petty 2007, p. 303). In the end it is a combination of student work and teacher interpretation or presentation.

\section{Discussion}

There are many similarities that exist between these three early childhood educational models. All offer non-traditional options for educators and have been established as strong alternative early childhood educational models for multiple decades. Reggio Emilia and Montessori approaches have been cited as "inspiration for progressive educational reform in the United States and around the world" (Edwards 2003 , p. 34). Each of these models began with leadership by a single person, and all three models have remained influential over time.

Reading and writing are emphasized in the Montessori curriculum but are not featured specifically for young children in Waldorf and Reggio Emilia schools (Edwards 2002; Edmunds and Barton 2004). Waldorf and Montessori use the idea of 'work' to describe the children's learning activities; Reggio Emilia prefers the term 'project.' Two of these programs offer curriculum extended through elementary school and even high school years: Montessori and Waldorf; Reggio Emilia schools service children through kindergarten only (Edwards 2002). Waldorf and Reggio Emilia share a special emphasis on the arts (Easton 1997) that is much less apparent in Montessori schools. Pretend play and fantasy are not part of the learning development focus of Montessori programs, but Waldorf is nearly the opposite, featuring episodes of dramatic imaginative play regularly (Nordlund 2013; Edwards 2002).

Assessment in all of these approaches is non-traditional, and instead is based on portfolios, documentation, and descriptive narratives of teacher observations (Edwards 2002). Children with special needs find a place in all of these models. All three models prefer the use of natural or very specifically designed learning 
materials. Montessori is unique in its continued use of materials designed over a hundred years ago. Reggio Emilia schools expand the use of materials to include everything possible in the learning development (Wien 2008). The three alternative approaches all educate with limited or no technology use.

Typically, Waldorf schools utilize one lead teacher, "selected by this steering committee...as the main lesson teacher" (Easton 1997, p. 91); in a Reggio Emilia classroom, a team of two teachers works together; and Montessori classrooms do not specify a needed number of teachers. Teachers guide children, research child needs, and present options within all of the models, especially in the Reggio Emilia programs (Lim 2004). The level of teacher dialogue with students differs for each approach: Montessori teachers operate as observers, while Reggio Emilia teachers participate in more discussion, and Waldorf teachers are very active in drama and storytelling but limit intervention during art work.

The community focus of each alternative model contrasts with the others. Montessori education includes the perspective of parents and children in structuring the curriculum, but much of it is guided by teachers' scripted presentation of planned materials. Reggio Emilia emphasizes educators' relationship with the community, with a large circle of included opinions and perspectives in the educational planning. Waldorf education leaves much of the development of the learning program up to the children's interests. Though these three models share many characteristics and all stand as excellent alternative options internationally today, the differences between the models provide parents and educators with clear reasons to choose one over the other.

\section{Implications for International Usage}

New educational models introduce cultural ideas and methods which may be different to those already offering within and across national contexts. Full adoption of an alternative education approach is not the only option. For example, Nordlund (2013) discusses transfer of early education models into other cultures, proposing the possibility of learning specific ideas from a method like Waldorf, gaining possible insight from these alternatives, and using parts of educational models in traditional educational settings. The point is that direct transfer of any alternative educational approach from one nation to another is not necessary or probably advisable; instead, educators can look for adaptation possibilities for the receiving culture and consider changing the model to fit the receiving culture. Miller (2011) and Duckworth (2006) both comment on this issue of adaptability, citing Montessori's flexibility internationally as a model. Miller (2011) believes that within the Montessori philosophy there is room for tolerance as different educators, parents, and physicians advocate different applications of supporting a child's development.

An important consideration in adapting a model from one culture into another educational system is the child and his/her understanding. In considering "young children's learning experiences, educators must realize contemporary cultural complexities in young children's lives, starting at their personal level. And educators ought to strive to understand how individuals' personal-level cultural complexities 
affect the collective wisdom of young children and their learning processes" (Hyun 2007 , p. 265). Educators love to study issues of theory and practice, and it may easy to get fascinated by a new idea, a concept which teachers feel is more interesting or better overall. In doing so, educators can forget the needs of the child, the understanding which they have or do not have about culture and learning, and their interests as the primary ones who should benefit from the educational experience. Papatheodorou (2006) states that without careful planning, incorporation of an alternative approach could "become another imposed framework, the underpinnings of which are vaguely or loosely understood" (p. 6).

Families in some cultures maintain high interest in specific scope and sequence, a written curriculum that is clearly designated and planned, even at the early childhood level. In these countries, the Reggio Emilia approach (and in some ways, Waldorf education as well) may not be accepted as sufficiently structured for strong development. Reggio's general emphasis on art and nature, and the flexible, unplanned storytelling of Waldorf, with no designated books or materials, may not present to parents a cohesive curriculum, with proof of goals and skills which will result from the education. Montessori, in contrast, provides very specific materials and developmental goals for children through use of those materials.

Across cultures, educators and parents may want children supported as they develop their own interests, but they may also want children to meet requirements that are important in the adults' minds for strong cognitive development to ensure later academic achievements. Educators and parents may not want the total freedom of the Reggio Emilia or Waldorf models because they feel the child may miss opportunities to learn and to be assessed as competent in important academic skills when they begin more formal schooling. Documentation, portfolio use, and observation would also be quite difficult to assimilate into many cultures that have never experienced the more nontraditional forms of assessments of skills and competencies that these alternative models utilize. For example, as Kroeger and Cardy (2006) have identified, the intriguing possibilities of Reggio Emilia assessment options are difficult for educators to implement if "their settings are still driven by accountability systems that demand children make progress on skill-based measures" (p. 393).

\section{Conclusion}

As modern education changes with technology and even in its reconceptualization of education, consideration of alternatives to traditional education, such as Montessori, Waldorf, and Reggio Emilia, is vital for progress. The best sources for learning about possible success or adaptive options are the comparative studies which have examined the use of these alternative methods in economically developed countries (Al-Mogbel 2014). But no culture's education develops without analysis of the appropriateness of new ideas within that specific context: "People develop as participants in cultural communities. Their development can be understood only in light of the cultural practices and circumstances... which also change" (Rogoff 2003, pp. 3-4). 
Modern research recognizes "the importance of pre-primary education and its implications academically, mentally, psychologically and socially with respect to the development of the child. This increased awareness has encouraged research in all countries of the world...to examine the role of this pre-primary stage in the formation of the child" (Al-Mogbel 2014, pp. 2072-2073). Supporting research of alternative educational models in early childhood education across the world is a worthy aim. It is important to invest scholarly time and effort in charting and evaluating these models of early childhood education across different cultural contexts. It is additionally valuable to consider cultural adaptations in future application of these models within early childhood education globally.

Acknowledgements First and foremost, praise and thank Allah for His blessings throughout my research work to complete the research successfully. I would like to express my deep and sincere gratitude to Ministry of Education in Saudi Arabia for giving me the opportunity to do research and providing invaluable guidance throughout this research. My completion of this project could not have been accomplished without the support of Dr. Abdulrahman Alasimi, Saudi deputy minister of education thank you for the opportunity, for the trust and the advice. I am extending my thanks to Ministry agency for general education and Early Childhood General Administration at Ministry of Education for support to do this work. I also thank Dr. Marth Lash, Associate Professor, ECED and C \& I IBPYP Coordinator at Kent State University. For her time and encouragement to complete this article. Finally, my thanks go to all the people who have supported me to complete the research work directly or indirectly.

Open Access This article is licensed under a Creative Commons Attribution 4.0 International License, which permits use, sharing, adaptation, distribution and reproduction in any medium or format, as long as you give appropriate credit to the original author(s) and the source, provide a link to the Creative Commons licence, and indicate if changes were made. The images or other third party material in this article are included in the article's Creative Commons licence, unless indicated otherwise in a credit line to the material. If material is not included in the article's Creative Commons licence and your intended use is not permitted by statutory regulation or exceeds the permitted use, you will need to obtain permission directly from the copyright holder. To view a copy of this licence, visit http://creativecommons.org/licen ses/by/4.0/.

\section{References}

Al-Mogbel, A. N. (2014). A proposal for the development of pre-primary education in Saudi Arabia based on the experiences of Malaysia and South Korea: A comparative study. Creative Education, 5(24), 2071-2089.

Barnes, H., \& Lyons, N. (2003). Education as an art: the Rudolph Steiner method. In C. A. Bärtges \& N. Lyons (Eds.), Educating as an art: Essays on Waldorf education (pp. 17-24). New York: Rudolf Steiner School.

Chauncey, B. (2006). The Waldorf model and public school reform. Encounter, 19(3), 39-44.

Clouder, C., \& Rawson, M. (1998). Waldorf education. Hudson, NY: Anthroposophic Press.

Cossentino, J. (2009). Culture, craft, and coherence: The unexpected vitality of Montessori teacher training. Journal of Teacher Education, 60(5), 520-527.

Crain, W. C. (2011). Theories of development: concepts and applications (Vol. 6). Boston, MA: Prentice Hall.

Damovska, L. (2005). The Waldorf pedagogy and children with special education needs. Journal of Special Education and Rehabilitation, 1-2, 35-42.

Dancy, R. B. (1989). You are your child's first teacher: What parents can do with and for their children from birth to age six. Berkeley, CA: Celestial Arts.

DeLuca, C., \& Hughes, S. (2014). Assessment in early primary education: An empirical study of five school contexts. Journal of Research in Childhood Education, 28(4), 441-460. https://doi. org/10.1080/02568543.2014.944722. 
Duckworth, C. (2006). Teaching peace: a dialogue on the Montessori method. Journal of Peace Education, 3(1), 39-53. https://doi.org/10.1080/17400200500532128.

Dodd-Nufrio, A. T. (2011). Reggio Emilia, Maria Montessori, and John Dewey: Dispelling Teachers' misconceptions and understanding theoretical foundations. Early Childhood Education Journal, 39, 235-237. https://doi.org/10.1007/s10643-011-0451-3.

Easton, F. (1997). Educating the whole child, "head, heart, and hands": Learning from the Waldorf experience. Theory into Practice, 36, 87-94.

Edmunds, F., \& Barton, M. (2004). An introduction to Steiner education: The Waldorf school. Forest Row [UK]: Sophia Books.

Edwards, C. P. (2002). Three approaches from Europe: Waldorf, Montessori, and Reggio Emilia. Early Childhood Research and Practice, 4(1), 1-14.

Edwards, C. P. (2003). "Fine designs" from Italy: Montessori education and the Reggio Emilia approach. Montessori Life, 15(1), 34-39.

Edwards, C., Gandini, L., \& Forman, G. (Eds.). (2012). The hundred languages of children: The Reggio Emilia experience in transformation (Vol. 3). Santa Barbara, CA: ABC- CLIO.

Firlik, R. (1996). Can we adapt the philosophies and practices of Reggio Emilia, Italy, for use in American schools? Early Childhood Education Journal, 23(4), 217-220.

Giroux, H. (1997). Pedagogy and the politics of hope: Theory, culture, and schooling. Boulder, CO: Westview.

Hall, K., Horgan, M., Ridgway, A., Murphy, R., Cunneen, M., \& Cunningham, D. (2014). Loris Malaguzzi and the Reggio Emilia experience. London: Continuum.

Hertzog, N. B. (2001). Reflections and impressions from Reggio Emilia: "It's not about art!" Early Childhood Research and Practice, 3(1), 1-10.

Humphryes, J. (1998). The developmental appropriateness of high-quality Montessori Programs. Young Children, 53(4), 4.

Hyun, E. (2006). Teachable moments: Re-conceptualizing curricula understandings. New York: Peter Lang.

Hyun, E. (2007). Cultural complexity in early childhood: Images of contemporary young children from a critical perspective. Childhood Education, 83(5), 261.

Kane, J. (2011). Toward living knowledge: A Waldorf perspective. Encounter, 24(2), 115-132.

Katz, L., \& Chard, S. C. (1996). The contribution of documentation to the quality of early childhood education. Urbana, IL: ERIC Clearinghouse on Elementary and Early Childhood Education, University of Illinois.

Kroeger, J., \& Cardy, T. (2006). Documentation: A hard to reach place. Early Childhood Education Journal, 33(6), 389-398.

Lash, M. (2008). Classroom community and peer culture in kindergarten. Early Childhood Education Journal, 36(1), 33-38.

Lewin-Benham, A. (2006). Possible schools: The Reggio approach to urban education. New York: Teachers College Press.

Lillard, A. (2005). Montessori: The science behind the genius. New York: Oxford University Press.

Lillard, A. S. (2013). Playful learning and Montessori education. American Journal of Play, 5(2), $157-186$.

Lillard, P. P. (1997). Montessori in the classroom: A teacher's account of how children really learn (Vol. 2). New York: Schocken Books.

Lim, B. Y. (2004). The magic of the brush and the power of color: Integrating theory into practice of painting in early childhood settings. Early Childhood Education Journal, 32, 113-119.

Malaguzzi, L. (1998). History, ideas, and basic philosophy: An interview with Lella Gandini. In C. Edwards, L. Gandini, \& G. Forman (Eds.), The hundred languages of children: The Reggio Emilia experience in transformation (pp. 49-98). Greenwich, CT: Ablex.

Miller, D. F. (2011). Montessori infant and toddler programs: How our approach meshes with other models. Montessori Life, 23(3), 34-39.

Montessori, M. (1967). The absorbent mind. New York: Holt, Rinehart, and Winston.

Mooney, C. G. (2013). Theories of childhood: An introduction to Dewey, Montessori, Erikson, Piaget and Vygotsky. St. Paul, MN: Redleaf Press.

New, R. S. (1992). The integrated early childhood curriculum: New interpretations based on research and practice. In C. Seefeldt (Ed.), The early childhood curriculum: A review of current research (pp. 286-322). New York: Teachers College Press. 
New, R. S. (2000). Reggio Emilia: Catalyst for change and conversation. Champaign, IL: ERIC Clearinghouse on Elementary and Early Childhood Education, University of Illinois.

Nordlund, C. N. (2013). Waldorf education: Breathing creativity. Art Education, 66(2), 13-19.

Olsson, L. M. (2009). Movement and experimentation in young children's learning: Deleuze and Guattari in early childhood education (p. 2009). New York: Routledge.

Papatheodorou, T. (2006). Seeing the wider picture: Reflections on the Reggio Emilia approach. Association for the Professional Development of Early Years Educators.

Phillips, D., \& Schweisfurth, M. (2008). Comparative and international education: An introduction to theory, method and practice. London: Continuum.

Rambusch, N. (1965). Introduction. In M. Montessori (Ed.), Dr. Montessori's own handbook. New York: Random House.

Rambusch, N. M. (2010). Freedom, order, and the child: Self-control and mastery of the world mark the dynamic Montessori method. Montessori Life, 22(1), 38-43.

Rathunde, K. (2001). Montessori education and optimal experience: A framework for new research. NAMTA Journal, 26(1), 11-43.

Rinaldi, C. (2001). The pedagogy of listening: The listening perspective from Reggio Emilia. Innovations in Early Education: The International Reggio Exchange, 8(4), 1-4.

Rinaldi, C. (2006). In dialogue with Reggio Emilia: Listening, researching and learning. London: Routledge.

Rogoff, B. (2003). The cultural nature of human development. Oxford: Oxford University Press.

Smith, O. (2013). The spirit of the teacher. Montessori Life, 25(3), 46-49.

Vakil, S., Freeman, R., \& Swim, T. J. (2003). The Reggio Emilia approach and inclusive early childhood programs. Early Childhood Education Journal, 30(3), 187-192. https://doi.org/10.1023/A:10220 22107610.

Valentine, M. (1999). The Reggio Emilia approach to early years education. North Lanarkshire, Scotland: Scottish Consultative Council on the Curriculum.

Walsh, B., \& Petty, K. (2007). Frequency of six early childhood education approaches: A 10- year content analysis of early childhood education journal. Early Childhood Education Journal, 34(5), 301-305.

Weinberg, D. R. (2011). Montessori, Maslow, and Self-Actualization. Montessori Life, 23(4), 16-21.

Wien, C. A. (2008). Emergent curriculum in the primary classroom: Interpreting the Reggio Emilia approach in schools. New York: Teachers College Press.

Publisher's Note Springer Nature remains neutral with regard to jurisdictional claims in published maps and institutional affiliations. 